\title{
The Sacred Space of Saint Paul the Apostle, Lyford Cay
}

\author{
William J. Fielding \\ Office of Institutional Strengthening and Accreditation \\ University of The Bahamas
}

\begin{abstract}
Saint Paul the Apostle, Lyford Cay, is the most westerly Catholic parish church on the island of New Providence, The Bahamas. It was established to meet the spiritual needs of Roman Catholics most removed from the island's city, Nassau, when a new community was being developed. The paper will demonstrate how the church building blends the "modern" style of architecture of the mid-20th century as well as Church tradition in its Bahamian architectural context.
\end{abstract}

\section{Introduction}

The most important gathering for Roman Catholics is that for the Mass. As a result the church, the space where that assembly occurs, should be conducive to the public rite of the Mass and accord with the General Instructions of the Roman Missal (United States Conference of Catholic Bishops, 2011). Notwithstanding the traditions associated with the celebration of the Mass, the Constitution on the Sacred Liturgy (Pope Paul VI, 1963) allows for local creativity in church design and art. The focus of this paper is to describe how St. Paul's, ${ }^{1}$ built in the mid-20th century, reflects the style of its day while marrying Church form and function (Anson, 1964) and traditional Bahamian architecture.

In brief, the physical structure of St. Paul's, which has remained unchanged since 1968, is built upon a rectangular plan (59 feet long and 39 feet 4 inches wide). The walls are made of concrete and the roof of wood. The original wooden shingled roof has been replaced by a

${ }^{1}$ St. Paul the Apostle, the church and parish are known locally as St. Paul's and that is the name used here; we refer to the Apostle Paul as Saint Paul.
Bermuda roof (Figure 1). ${ }^{2}$ Inside, there is a wooden ceiling supported by beams and concrete posts concealed using pilasters. The walls along the nave are dominated by louvered doors and a clear story, which add to a feeling of space arising from the open plan (no side chapels or altars) of the worship space.

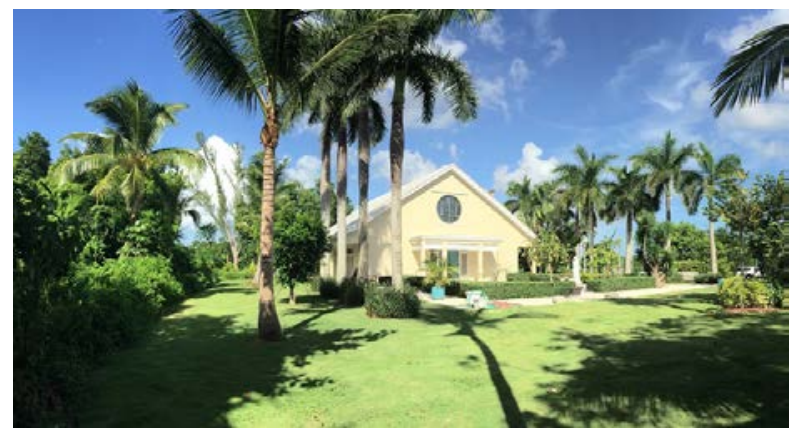

Figure 1. St. Paul's circa 2018.

The word church has two distinct meanings as it can refer to a place or a community of worshippers. Church ${ }^{3}$ as a community of people who assemble to pray and participate in the Eucharistic meal can be appreciated

\footnotetext{
${ }^{2}$ All pictures belong to the author unless otherwise credited.

3 "Church" with a capital " $C$ " will be used to denote the Roman Catholic Church.
}

(c) W. J. Fielding. https://orcid.org/0000-0001-5433-9673

(C) International Journal of Bahamian Studies, 2018. https://doi.org/10.15362/ijbs.v24i0.310 
from the epistles of Saint Paul who wrote to such "churches" (Coriden, 1997). Further, in the context of a parish, the meaning of the word church, ekklesia in Greek, can be taken as referring to a small community of believers, such as members of a particular parish church, rather than groups of communities.

The concept of a parish emerges from the third century as missionary activities resulted in Christian communities outside urban areas (Coriden, 1997). Until that time, the Church's activities had been focused on towns, as can be appreciated through Saint Paul's letters. The increase in the number of communities and their associated places of assembly meant that bishops could no longer provide for the pastoral needs of those in their care, and hence the requirement for priests and deacons to assist bishops. In the second century, Saint Ignatius of Antioch extols the need for the community to be united with their bishop and deacons. In time, travelling priests provided pastoral care to small outlying communities. This is evident in the rise of mendicant orders who brought the sacraments and preaching to rural communities. Only when a community became sufficiently large, was a priest assigned. Of the reasons for establishing a church, one that is relevant in the context of St. Paul's is that landowners built churches to provide for the spiritual needs of those living on their land, often their employees or serfs (Coriden, 1997). St. Paul's mimics this to the extent that it was built at the suggestion of the landowner, not for his employees, but for those buying lots in his development (Eileen Kistler, personal communication, May 12, 2018).

\section{Building the Space - the Need}

After World War II, an exclusive enclave was built at Lyford Cay on the western end of New Providence. In 1960, the owner, E. P. Taylor (1901-1989) invited the diocese to build a church inside the gated community to serve the spiritual needs of its residents. However, Bishop Paul Hagarty (1909-1984) did not want the church built inside the gated community as this would restrict its access (St. Paul The Apostle Catholic Church Lyford Cay, undated). Bishop Hagarty's genius was to build a visible church (dedicated on March $17,1968)$ on a hilltop, accessible to everyone, so reflecting the Church's mission (Mark 16:15). Therefore, the location of St. Paul's is a key aspect of its theology. The consequence of placing the church in a restricted area, where only wealthier residents live, would have contradicted Christ's concern for poor and vulnerable members of society and the Church's social teachings (Pontifical Council for Justice and Peace, 2014). Monsignor Preston Moss has described St. Paul's as "St. Paul's outside the walls" (Mons. P. Moss, personal communication, January 24, 2018), which appreciates a connection to the Papal basilica of the same name dating back to 324, as well as being a church belonging to a wider community beyond any enclosed enclave.

\section{St. Paul's and the Architectural Tradition of the Universal Church}

In the overall milieu of church architecture, the grand cathedrals which dot Europe, etc. are the best known but they are also the exceptions, inasmuch as most of the faithful worship in parish churches rather than cathedrals or basilicas. As such, it is parish "church buildings [which] tell the stories of the local church and how it is connected to the larger body of history, scripture and tradition" (Vosko, 2006, p. 8). St. Paul's includes architectural elements which can be seen in medieval churches as well as those situated in "modern" post-World War II trends in household and church design.

A church must be "both the house of God on earth (domus Dei) and a house fit for the prayers of the saints (domus ecclesiae)" 
(Stroik, 2012, p. 15). Therefore, it "must be expressive of the presence of God and suited for the celebration of the sacrifice of Christ, as well as reflective of the community that celebrates there" (United States Conference of Catholic Bishops, 2000). This observation raises a tension between the church as a space for organised liturgy and a space where the faithful come, either singly or in community, to pray. Both activities, the communal and the individual, are essential parts of a balanced spiritual life-Jesus' life demonstrates this; he attended synagogues, but also made time for private prayer (Mark 1: 35-39) — and a church needs to accommodate both (Stroik, 2015).

The trend in church design, prior to the Second Vatican Council, led to focussing on the liturgical function. This move was apparently endorsed by the documents from the Council and reinforced by regional bishops. The modernist trend in church design coincided with such statements on church buildings. They combined to reinforce the functional, liturgical use of churches. As such, this move tended to at least sideline the fact that the "ecclesia is not just those living on earth; it also includes those who enjoy the rewards of heaven” (Rofe, 2002).

If it is accepted that "it is the Church that gives shape to a church" (DeBoer, 2016, p. 101) then St. Paul's can be seen to reflect its times, both in the prevailing Church guidelines on church design as well as secular architecture. St. Paul's is an early postVatican Council II (1962-1965) church built in accordance with the changes that arose from the Council (Pope Paul VI, 1963), but it also reflects the guidelines of Pope Pius XII's encyclical Mediator Dei of 1947 (Pope Pius XII, 1947), such as its incorporation of "modern" art and the importance of the active participation of all in the Eucharistic celebration.
It is apparent that the church's simple, unfussy, altar-focused design situates it in the initial response of church design to the Council when the liturgical function of churches was emphasised. The design of the church also arises from the architect's response to the surrounding environment; an appreciation that extends to the choice of colours used in the stained glass (Schmid, 1969). The stained glass connects the church with the tradition of stained glass windows, notably in the great cathedrals of Europe, and locally in the Catholic cathedral in Nassau.

The assimilation of the environment and the incorporation of local architectural elements reflects the long-standing tradition, endorsed by Pope Gregory the Great, of the Church appropriating local tradition and culture, as exemplified in stave churches (Murphy, 2013). St. Paul's continues a tradition of churches in post and beam design. In St. Paul's, purlins running perpendicular to the rafters support the sheathing boards of the roof and the concrete "posts" are concealed within pilasters. Variations of (originally timber framed) post and beam techniques were used in medieval churches, including the Basilica of old Saint Peter's in Rome according to a reconstruction by Filippo Gagliardi, and the church of the Nativity in Bethlehem (Stroik, 2012), and also modern churches such as Saint Peter's church, Boerne (Vosko, 2006).

Further, what might be regarded as characteristics of St. Paul's have been used in more recent churches, such as Saint Sebastian, Bryon Center, Michigan (DeBoer, 2016). This suggests that the post-Council views still influence church design and so locates St. Paul's in the continuing development of church architecture.

\section{The Bahamian Architectural Tradition in St. Paul's}

While St. Paul's reflects the shape of the first 
house churches (rectangular; Anson, 1964), it includes aspects that are traditional of Bahamian architectural design. Bahamian architecture reflects much that is common throughout the wider Caribbean Region (Slesin et al., 1985) and is rooted in its colonial heritage emanating primarily from Great Britain (Mouzon, 2007).

The most well-known Catholic church architect in The Bahamas is Monsignor John Hawes (1876-1956) who built churches and other structures both inside and outside The Bahamas (Anson, 1957). His style of architecture is rooted in traditional European designs, as can be appreciated by the use of domes and towers. Yet despite his fame, his influence has had limited impact on local Catholic church design.

St. Paul's is removed from the "Hawes" style. The pre-Vatican Council II modernist trend in secular architecture is a possible motivation behind the spare design of St. Paul's as much as Sacrosanctum Concilium of 1963 (Pope Paul VI, 1963), published just three years before work on St. Paul's started. The architect of St. Paul's was Eldredge Snyder (1901-1967) who obtained a Master's degree in architecture from the University of Pennsylvania. He studied at the American Academy in Rome in 1927-28 (Landmarks Preservation Commission, 1981); so we can expect that the churches in the Eternal City and beyond would have impressed him.

In New York, he designed houses in rich communities such as Rhode Island and Nantucket, as well as "contemporary" style dormitories for Oberlin College (Oberlin College Archives, 2015). Snyder was considered a "modernist" (Nelson \& Wright, 1945) and contributed to a movement in the 1950s which encouraged people to build simple, open-plan houses, using post and beam design, with extensive windows. These were termed "Eichler" homes after their leading exponent Joseph Eichler (1900-1974), who in turn had been influenced by the modernist Frank Lloyd Wright (1867-1959; "The wonderful world of Eichler Homes", 2016). Snyder, too, has been considered a "Wrightian" (Penick, 2007).

Snyder designed at least one church, Saint David's Episcopal Church, Kinnelon, NJ (Read, 2009) which was "modern" yet not dissimilar in style to St. Paul's or Eichler homes. The similarities between the "Eichler house” (Figure 2), St. David's (Figure 3) and St. Paul's cannot be ignored; these include large windows, extended eaves, and post and beam construction giving a spacious, clean, unfussy appearance to the structure. Eichler houses, based upon "post and beam" construction, also had large windows (McLauglin, 2010) - these features are found in St. Paul's. Therefore, the lines between a House of God, domus dei, and House of the Church, domus ecclesiae (Stoik, 2012), become blurred as the architectural style of St. Paul's suggests one which has grown out of a house church with similarities with domestic house design.

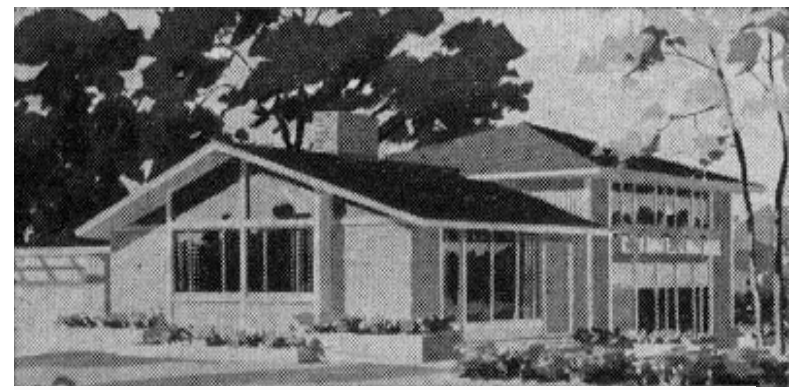

Figure 2. Snyder's design for a house, 1956 (Harris, 2013).

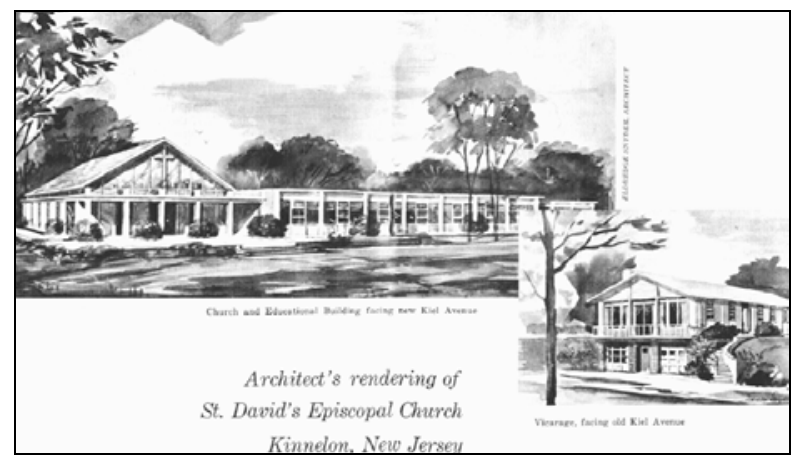

Figure 3. Snyder's design for a church, 1962 (Read, 2009). 
In The Bahamas, Snyder designed buildings inside the gated community of Lyford Cay (Lupu, 2012), including the club building by the pool, in a clean modern style (Aarons, 1962). He also reworked the BritishAmerican Insurance Office (Phillips, Davidson, \& Thurlow, 2014) in sympathy with Bahamian architectural design, exemplified by his extensive use of louvers.

Snyder's ability to marry modern and traditional styles was also illustrated in his design for a Chinese complex at Harvard University (Roskam, 2010). Consequently, it can be appreciated that Eldredge Snyder had experience in designing buildings in modern styles yet he was also sympathetic to tradition, so making him equipped, by training and experience, to design St. Paul's (Figure 4).

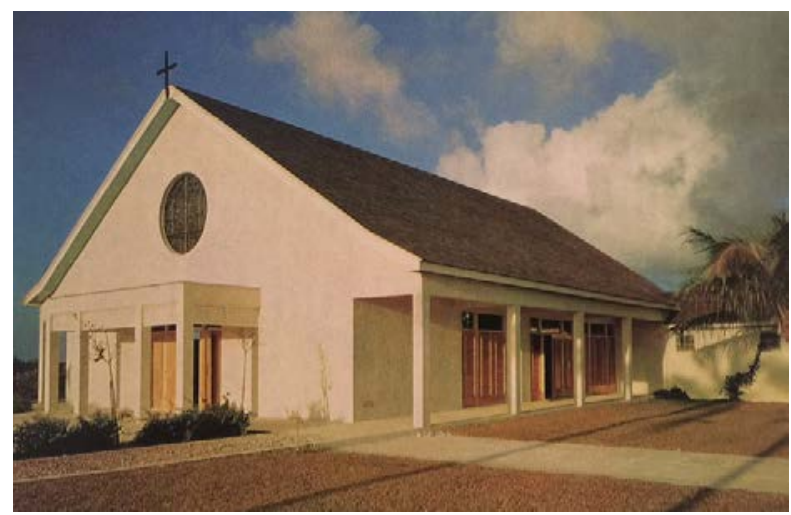

Figure 4. St. Paul's circa 1969 (Schmid, 1969).

\section{St. Paul's: Where Design and Theology Meet}

The vision of Bishop Hagarty and the sympathetic marrying of Snyder's "modern" architecture with traditional designs meet at St. Paul's. This can be discerned by the fact that in his homily at the dedication, Bishop Hagarty singled out the contribution of Snyder to the building of St. Paul's ("Bishop Leonard Dedicates Church”, 1968).

St. Paul's is situated on a small hilltop and parishioners must approach the church by travelling up the slope. This resonates with passages from Holy Scripture-_"Who may go up the mountain of the Lord?" (Psalm 24:3), the unity of nations (Isaiah 2:2-3), the crowds gathering to hear Christ preach the Sermon on the Mount and with the idea that God's Word is a light to the world, a sign of God's presence.

Wide stairs to the plaza of the church place the church above the level of the car park. This elevated position points to otherworld realities. Plazas are traditional places for gatherings and promote a feeling of community within the worshippers. The plaza links the Christians of St. Paul's with the wider Christian community and with both the Jewish (the Temple precincts) and Islamic (the environs of the Ka'bah in Mecca) traditions (Vosko, 2006).

The plaza (Figure 5) plays an important role during Easter celebrations (the Palm Sunday Procession and the ritual around the fire at the Easter Vigil). It includes a statue of Mary (Figure 6) and benches where people can sit and pray. Marian devotion is consistent with the reforms of the Council of Trent and medieval cathedral tradition (Coriden, 1997), and so is another aspect of St. Paul's expressing continutity with Church treaching and tradition.

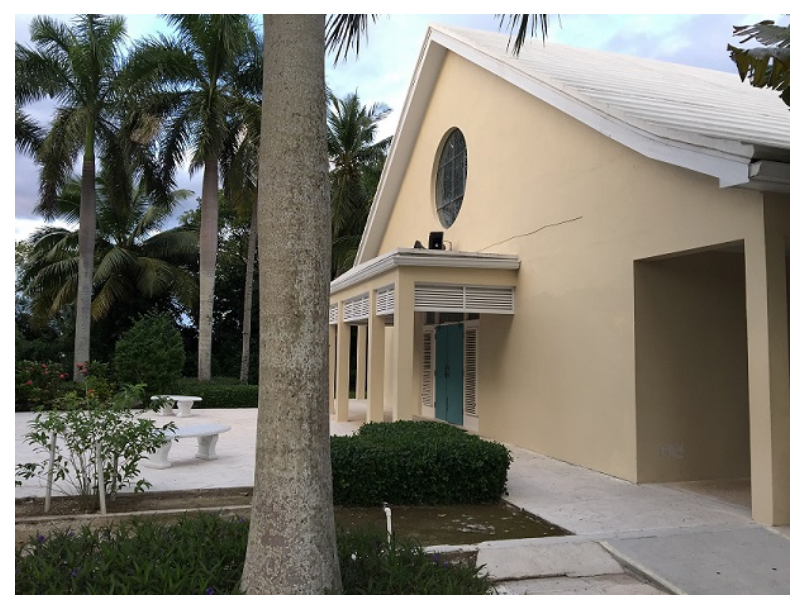

Figure 5. The plaza and narthex at St. Paul's. 


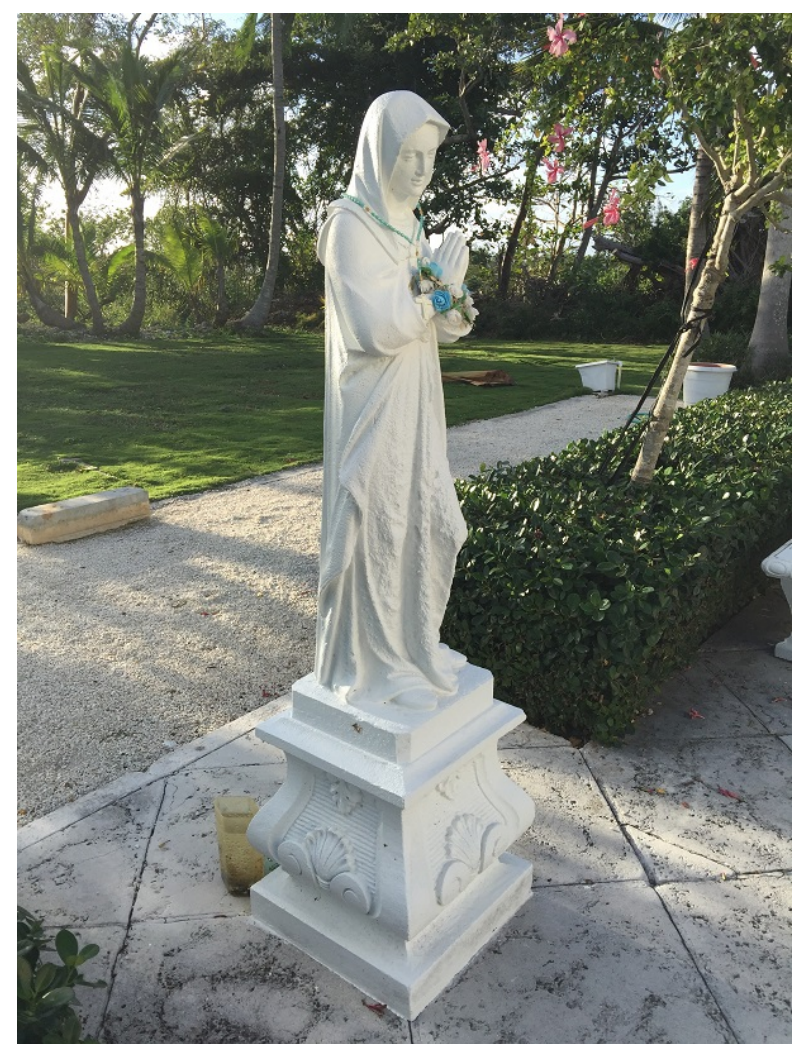

Figure 6. Our Lady of Prayer in the plaza.

While St. Paul's lacks a grand entrance door, it has double doors that accommodate processions and, combined with the narthex, clearly demonstrate that this is the main entrance. The lack of overt grandeur of the doors might be considered an understated indication that behind the doors is a special space; that the doors are a "holy gate through which the faithful enter into the joy of the Lord” (Rogerson, 1971). Nonetheless, in the Bahamian context, the double door entrance would be considered an "organic" design, one that arises from the vernacular (Mouzon, 2007, p. 11 \& p. 88), and its width clearly marks this as the main entrance.

Rather than relying only on a clerestory for light, louvered doors along the nave provide additional light (Figure 7). These also keep out the rain and allow for cross ventilation. Louvers are another traditional feature of Bahamian building design (Mouzon, 2007). The extent of the louvers along the nave almost gives the impression of a "reclaimed porch" (a porch which is sometimes used as a living space; Mouzon, 2007, p. 132). For a church dedicated to Saint Paul, the open sided feel of the church might be considered appropriate for a tent maker. Galleries on the southerly and northerly sides reduce the amount of sunlight directly entering the church. They contribute to cooling the church interior and allow the louvered doors to remain open even in rain. They also give the space a sense of continuity with the natural environment. This offers a different feel to that of classical churches which shut out their surroundings.

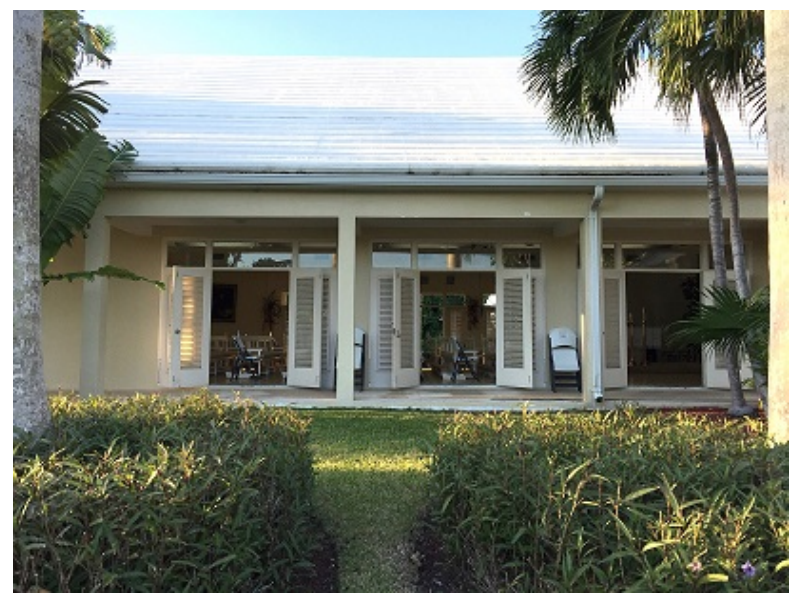

Figure 7. The open southern louvered doors and gallery.

The open-plan nature of St. Paul's is consistent with creating a "sense of communal gathering”, a concept which had been used in 1923 by August Perret (Vosko, 2006, p. 34). The aim of engaging the congregation as participants rather than observers of liturgy was an important objective of the liturgical movement leading up to Vatican Council II and had been anticipated in the 1800s (Vosko, 2006). It represented a desire to recreate the experience of the Christian community in house churches and early basilicas. The combination of the traditional, rectangular shape of the church, its feeling of height with the open beam roof, and its feeling of being without walls when the louvered doors are open, results in a synthesis of the horizontal 
approach to a church whereby the congregation is an active participant in the liturgy. The size of St. Paul's gives a feeling of immediacy to the liturgical action. ${ }^{4}$

St. Paul's also reflects the theology articulated by Hans Urs Von Balthasar of the vertical inbreaking of God into history (Von Balthasar, 1994). This espouses the vertical approach to a church where the hierarchy of sacrificial victim, priest and congregation is also apparent, reflecting the transcendent nature of the Mass; being both of this world and pointing to something beyond it (Vosko, 2006). The vertical nature of the church is subtly reflected in a trinity of levels: the lowest level where the congregation sits, the second level that of the altar, clergy and ambo, and the third and highest level where the tabernacle is situated. While these levels acknowledge a hierarchy (Pope Pius XII, 1947), within the unity of worship the differences in elevation are slight and so the arrangement reinforces the communal sense. This presents a theology that lifts the eyes upwards towards heaven, the goal of all the faithful. The current placement of the altar and tabernacle locates St. Paul's in the tradition of renaissance and baroque churches of making the tabernacle the centre of the building, rather than the basilica tradition where the presider's seat is central. The window above the tabernacle also acts as a visual sign of transcendence.

An advantage of post and beam designs is that they raise the ceiling and so cool the interior (Mouzon, 2007). The high roof reinforces the feeling of looking up to heaven and allows "the smoke of incense along with the prayers of the holy ones" to rise "up before God" (Revelation 8:4). The use of wood is a

${ }^{4}$ The church measures 59 feet long and 39 feet 4 inches wide. The ratio of these measurements,

1.66 , is close to the Golden Mean of 1.62, and so explains the pleasing aspect of the space.

(Author's measurements). dominant feature of the ceiling. The significance of wood resonates with Noah's Ark and the wood of the cross. Also, wood is a traditional material in colonial structures so it situates the church in an ecclesial and social context (Turner, 2014). While the beams are unadorned, unlike the angel churches of East Anglia (Rimmer, 2014), during the Christmas season they are decorated to raise the eyes to imagine the heavenly host (Luke 2:14). This again helps to focus the believer on the upward, heavenly goal of eternal life, "above” this world. The beams create a simple geometric design (Figure 8) reflecting a modern sensibility but also having universal appeal to the "order and perfection of heaven" (McNamara, 2009). As such, the ceiling could be considered a visual representation of order arising at the creation (Genesis 1:1-2).

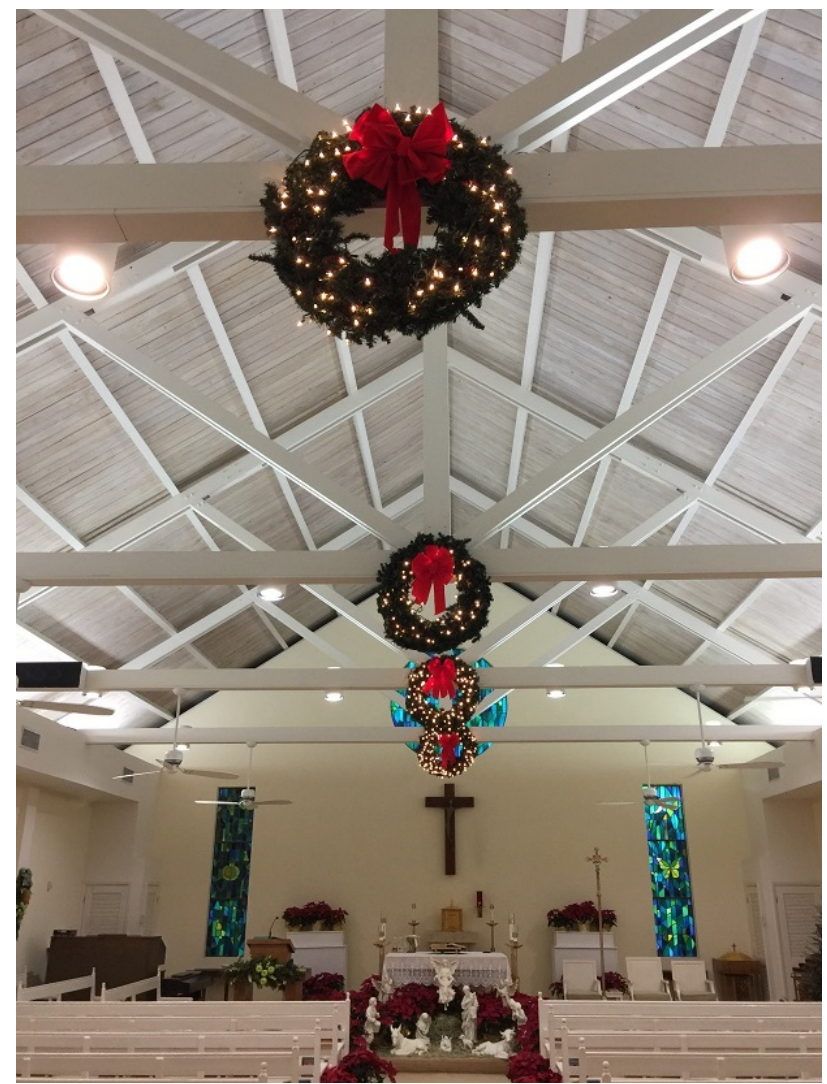

Figure 8. Decorated beams, Christmas 2017. 


\section{The Altar}

The altar is central to the sacrifice of the Mass. In keeping with the tradition of having stone altars in churches (Stroik, 2015), the marble altar is the focus of both the sanctuary and the congregation as the sight lines align with the altar, which sits on a platform above the level of the pews. The simplicity of the altar invites decoration consistent with the liturgical seasons. Altar clothes with varying degrees of ornamentation supply this. For example, during Lent a simple altar cloth is used which emphasizes the austerity of the season (Figure 9).

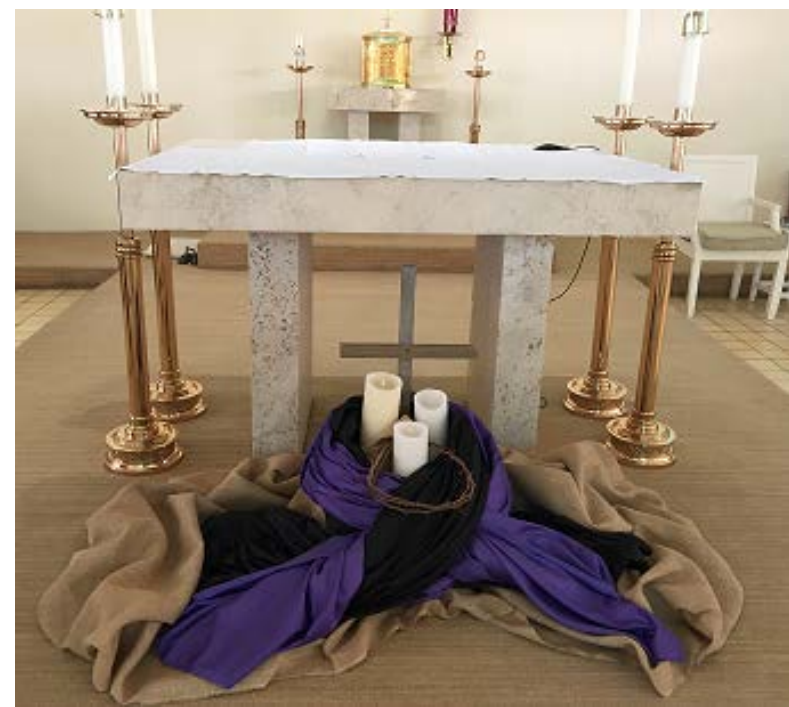

Figure 9. The altar, Lent, 2017.

\section{The Tabernacle}

For many Catholics, the presence of God in the church is what most clearly distinguishes a Catholic Church from other churches (Stroik, 2015). It is, therefore, central to the individual spiritual life of the faithful, particularly when the Blessed Sacrament is exposed. The tabernacle in St. Paul's was originally located to the right of the altar with the presider's chair centrally behind the altar, as in a basilica (Anson, 1964). This resulted in the attention of the faithful being divided between the altar and the tabernacle. This tension reflects the dual role of a church, a place of sacrifice and a place of private prayer. To some, this original arrangement might have given the impression that the centre of focus in the church was the altar and presider rather than the presence of God. While this is appropriate for the liturgy of the Mass, it is less appropriate for private prayer. Placing the tabernacle centrally behind the altar brings the Real Presence to the centre of the church, in keeping with Renaissance parish churches (Anson, 1964), although this location can seem less appropriate, given the changes since Vatican Council II, when the priest faces the congregation during mass.

A new tabernacle was dedicated in St. Paul's in 2014. It is adorned with scenes from the life of Christ and crowned with a cross, making it a more traditional vessel than the original. The tabernacle from the 1960s was adorned with coloured images of bread and chalice in a direct simple design consistent with the design of the building. The elevated position on a platform above the level of the sanctuary further increases the visibility of the tabernacle.

The connection between the altar and tabernacle is made through their central location in relation to the apse wall and the similar stone used for the altar and the tabernacle plinths. This makes these two central items a "pair". The use of stone sets them apart from the rest of the wooden furniture in the church. The differing durability of stone and wood also adds to a feeling of the enduring nature of the sacrifice of Christ and contrasts with the passing nature of earthly things.

\section{The Crucifix}

The cross is the altar upon which the Lamb of God was sacrificed and the cross and crucifix soon became symbols associated with Christianity (Marucchi, 1907). St. Paul's once had a cross on the roof (Figure 4). 


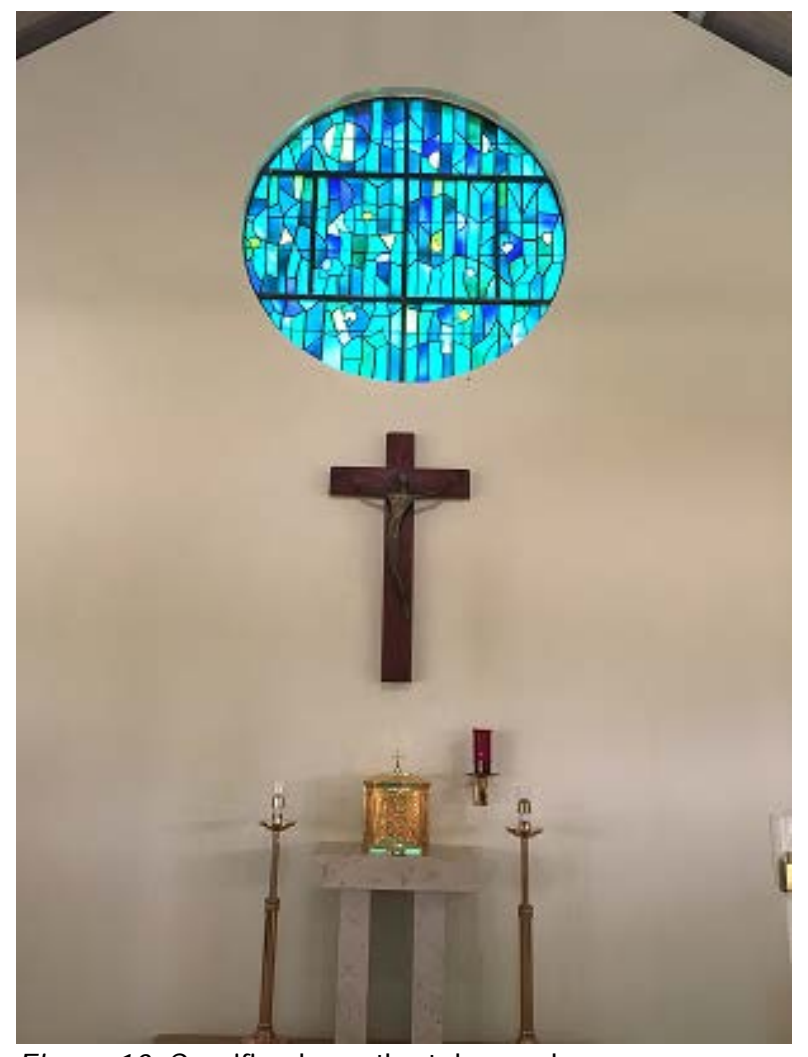

Figure 10. Crucifix above the tabernacle.

From the medieval period, a centrally located crucifix above the altar has been a feature of churches and is an important visualization of Christ's passion and death (Visel, 2016). The large crucifix in St. Paul's dominates the apse (Figure 10) and nave (Figure 11) in part due to the wood of the cross contrasting with the pale coloured wall. This is appropriate given that Christ crucified was a central message of Saint Paul (1 Corinthians, 1:23). The depiction of Christ on this crucifix makes no attempt at realism. It is a distorted body which appears small compared to the cross and so focuses attention on the cross rather than the figure. This representation of Christ suggests a body poured out for others (Philippians, 2:7) to the extent that only a little flesh is left on the bones. Given that Christ gives his flesh in the Eucharist, this bony Christ has strong theological connotations. This depiction is different to, say, medieval images which show Christ with arms outstretched to embrace us, or a head leaning down to kiss us (Lipton, 2005). Further, this minimalistic Christ is faceless, lacking detail. This "modern" depiction of Christ suggests a low Christology, that of a man bruised beyond recognition (Prayer to the Holy Face, 1906), a man disfigured. Therefore, it can invite worshippers to appreciate Christ's suffering for their sins. The lack of a recognizable face also allows the faithful to see themselves on the cross; they too have a share in Christ's suffering, death and resurrection.

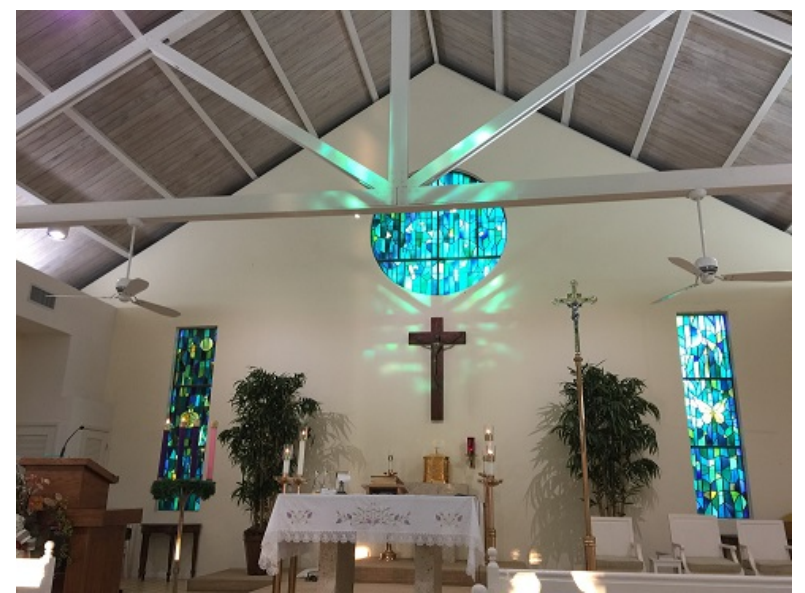

Figure 11. The interior of St. Paul's, 2017.

\section{Conclusion}

Building St. Paul's on a gentle hilltop accessible to all situates the building in the mission of the Church to bring Christ to the nations and to be a visible sign of Christ in the world. St. Paul's was designed in the modern style of architecture of the mid-20th century and is consistent with the contemporary thoughts of church architectural design emanating from Rome. Snyder's design for St. Paul's synthesizes modern and Bahamian traditions in architecture with traditional aspects of church building. 


\section{Acknowledgements}

The author is grateful to Father Kenny Forbes and parishioners for sharing their documents about St. Paul's, to Virginia Ballance for locating texts on Bahamian architecture and the Catholic Church in The Bahamas, and to Father Harry Hagan OSB of Saint Meinrad Archabbey for his supervision.

\section{References}

Aarons. S. (1962). Poolside service, Lyford Cay Club, Bahamas (Slim Aarons Estate Edition). Retrieved from https://www.1stdibs.com/art/photography/c olor-photography/slim-aarons-poolsideservice-lyford-cay-club-bahamas-slimaarons-estate-edition/id-a_1207513/\#0

Anson, P. F. (1957). Hermit of Cat Island: The life of Jerome Hawes. New York, NY: P. J. Kennedy \& Sons.

Anson, P. F. (1964). The building of churches. New York, NY: Hawthorn Books.

Bishop Leonard dedicates Church. (1968, March 18). The Tribune (Nassau: Bahamas), p 10.

Coriden, J. A. (1997). The parish in Catholic tradition: History, theology and canon law. New York, NY: Paulist Press.

DeBoer, L. J. (2016). Visual arts in the worshiping church. Grand Rapids, MI: Eerdmans.

Harris, D. (2013). The home show: Televising the postwar house. In Little white houses: How the postwar home constructed race in America (pp. 228-251). Minneapolis: University of Minnesota Press.

Landmarks Preservation Commission (New York). (1981). Upper East Side historic district designation report, Vol. 4. New York, NY: Author. Retrieved from http://neighborhoodpreservationcenter.org/ db/bb_files/uesvol4.pdf

Lipton, S. (2005). "The sweet lean of His head": Writing about looking at the Crucifix in the high Middle Ages. Speculum, 80(4), 1172-1208. Available at http://www.jstor.org/stable/20463497 .

Lupu, A. (2012, February 20). 50th anniversary celebrations: E. P. Taylor and the Lyford Cay International School. The Bahamas Weekly. Retrieved from http://www.thebahamasweekly.com/publis h/community/50th_Anniversary_Celebratio ns_E_P_Taylor_and_The_Lyford_Cay_Int ernational_School20388.shtml

Marucchi, O. (1907). Archæology of the cross and crucifix. In The Catholic Encyclopedia (12th ed., Vol. 4, pp. 517-529). New York, NY: Robert Appleton. Retrieved from http://www.newadvent.org/cathen/04517a. htm

McNamara, D. (2009). Bearers of the heavenly Jerusalem: Vatican II and development in church architecture. The Institute for Sacred Architecture, 15. Retrieved from http://www.sacredarchitecture.org/articles/ bearers_of_the_heavenly_jerusalem_vatica n_ii_and_development_in_church_arch

Mouzon, S. A. (2007). A living tradition: Architecture of the Bahamas. Miami Beach, FL: New Urban Guild Foundation.

Murphy, G. R. (2013). Tree of salvation, Yaggradsil and the Cross in the north. New York, NY: Oxford University Press.

Nelson, G., \& Wright, H. (1945). Tomorrow's house: How to plan your post-war home now. New York, NY: Simon and Schuster.

Oberlin College Archives. (2015). Harkness House. Retrieved from Oberlin College Library website 
http://www.oberlinlibstaff.com/omeka_oca /items/show/177

Penick, M. M. (2007). The pace setter houses: Livable modernism in postwar America. (Doctoral dissertation, University of Texas at Austin). Retrieved from http://www.library.utexas.edu/etd/d/2007/p enickm28579/penickm28579.pdf

Phillips, P. R., Davidson, G. C., \& Thurlow, D. J. (2014). The story of the British American Insurance Company. Retrieved from https://sites.google.com/site/thestoryofbriti shamerican/chapter-4-places

Pontifical Council for Justice and Peace. (2014). Compendium of the social doctrine of the Church. Washington, DC: USCCB Communications. Retrieved from http://www.antoniano.org/carbajo/FST/Rea dings/Magisterium/EN_Compendium_CST .pdf

Pope Paul VI. (1963). Sacrosanctum Concilium. Constitution on the Sacred Liturgy. Retrieved from http://www.vatican.va/archive/hist_council s/ii_vatican_council/documents/vatii_const_19631204_sacrosanctumconcilium_en.html

Pope Pius XII. (1947). Mediator Dei. Encyclical letter. Retrieved from http://w2.vatican.va/content/piusxii/en/encyclicals/documents/hf_pxii_enc_20111947_mediator-dei.html

Prayer to the Holy Face. [Prayer card]. (1906). S.l.: s.n.

Read, P. M. (2009). Anglicans in North Jersey: The Episcopal Diocese of Newark. Charleston, SC: Arcadia.

Rimmer, M. (2014). Angel roofs of East Anglia. The Mortise and Tenon, 57, 8-22. Retrieved from http://4ormatasset.s3.amazonaws.com/vfs/15399/public
_assets/11753311/M\%20T57\%20.pdf

Rofe, S. (2002). Vatican II, church architecture and "reform of the reform". AD2000, 15(6). Retrieved from http://www.ad2000.com.au/vatican_ii_chur ch_architecture_and_reform_of_the_refor m_july_2002

Rogerson, R. W. K. C. (1971). Symbolism in church architecture. Liturgical Studies, 1(1), 56-63. Retrieved from http://www.churchservicesociety.org/sites/ default/files/journals/1971-May-56-63.pdf

Roskam, C. (2010). The Golden Temple at Harvard. Harvard-Yenching Newsletter Institute, 2-4. Retrieved from https://www.harvardyenching.org/sites/harvardyenching.org/files/HYI_Fall_2010_Newsle tter.pdf

Schmid, E. (1969). Beholding as in a glass. New York, NY: Herder and Herder.

Slesin, S., Stafford, C., Berthelot, J., Gaumé, M., Rozensztroch, D. \& de Chabaneix, G. (1985). Caribbean style. London, Eng.: Thames \& Hudson.

St. Paul The Apostle Catholic Church Lyford Cay. (undated). Unpublished manuscript.

Stroik, D. G. (2012). The church building as a sacred place: Beauty, transcendence, and the eternal. Chicago, IL: Hillenbrand.

Stroik, D. G. (2015). Church architecture since Vatican II. The Jurist in Church Law and Ministry, 75(1), 5-34.

https://doi.org/10.1353/jur.2015.0009

The wonderful world of Eichler homes. (2016). Retrieved from http://www.eichlernetwork.com/article/wo nderful-world-eichler-homes

Turner, E. (2014). “On wooden churches”: William Scott and the colonial church. Religion and the Arts, 18, 297-324. https://doi.org/10.1163/15685292- 
01803001

United States Conference of Catholic

Bishops. (2000). Built of living stones: Art, architecture and worship: Guidelines of the United States Conference of Catholic Bishops. Washington, DC: Author.

Retrieved from http://www.sfdslg.org/Church/Documents/ ChurchReno/Built\%20of\%20Living\%20St ones.pdf

United States Conference of Catholic Bishops. (2011). General instruction of the Roman missal. Washington, DC: Author. Retrieved from https://www.liturgyoffice.org.uk/Resources /GIRM/Documents/GIRM.pdf

Visel, J. (2016). Icons in the western church: Towards a more sacramental encounter. Collegeville, MN: Liturgical Press.

Von Balthasar, H. U. (1994). Theo-drama: Theological dramatic theory, IV The action. San Francisco, CA: Ignatius Press.

Vosko, R. S. (2006). God's house is our house: Re-imagining the environment for worship. Collegeville, MN: Liturgical Press. 